\title{
Pohlia australis sp. nov. (Musci) from New Zealand with notes on some other austral Pohlias
}

\author{
JONATHAN SHAW \\ National Museum of Natural History \\ Smithsonian Institution \\ Washington, D.C. 20560, USA \\ ALLAN J. FIFE \\ Botany Division, DSIR \\ Private Bag, Christchurch, New Zealand
}

\begin{abstract}
Pohlia australis, a new gemmiferous species, is described from the South Island, New Zealand. A key is provided to distinguish the three New Zealand species of Pohlia bearing axillary gemmae ( $P$. australis, $P$. camptotrachela, and $P$. ochil). Pohlia tenuifolia, formerly thought to be endemic to Australasia, is reported from two localities in South America (Chile and Brazil).
\end{abstract}

Keywords Pohlia australis; P. ochii; P. camptotrachela; $P$. tenuifolia; Mielichhoferia brachycarpa; Bryaceae; gemmae; phytogeography

\section{INTRODUCTION}

Compared with Northern Hemisphere temperate regions of similar area, New Zealand has relatively few species of Bryaceae. Only five of the thirteen bryaceous genera are represented in the flora, and such genera as Brachymenium, Pohlia, and Mielichhoferia, which are quite diversified in other areas, have a few indigenous species in New Zealand. In Australasia as a whole, there are no endemic bryaceous genera, and the number of endemic species also appears to be low (Sainsbury 1955, Ochi 1970, Scott \& Stone 1976, Catcheside 1981).

The genus Pohlia is primarily north-temperate in distribution, penetrating the tropical latitudes only at high elevations. The Australasian flora includes few species of Pohlia and only about eight species occur in New Zealand. Several of these, including P. nutans (Hedw.) Lindb., P. cruda (Hedw.) Lindb., and $P$. wahlenbergii (Web. \& Mohr) Andr., are

Received 21 June 1984; accepted 19 November 1984 widespread in the Northern Hemisphere and occur disjunctively in Australasia and a few subantarctic localities. A gemmiferous Pohlia, P. camptotrachela (Ren. et Card.) Broth., previously reported only from western North America and western Europe (Shaw 1981, 1982; Smith 1978), was recently recorded from New Zealand for the first time (Fife 1984). Although long-term persistence cannot be entirely ruled-out, such disjunct occurrences of species that are common and widespread in the Northern Hemisphere suggest long range dispersal from north to south. Pohlia nutans and P. cruda are paroicous, whereas $P$. wahlenbergii, and $P$. camptotrachela are dioicous. Dispersal of the last species is probably facilitated by the production of gemmae.

The number of Pohlia species truly endemic to New Zealand must remain unknown until a revision of the southern temperate species in the genus is completed. One common New Zealand species, $P$. tenuifolia (Mitt.) Jaeg., reported from New South Wales by Scott \& Stone (1976), also occurs in two countries in South America. There it was first collected by P. Dusén in 1896 (Chile australis ad Puerto Veras in terra, Dusén 754; BM-Hampe!). Dusén called the plant Webera paucifolia Dus., and the name was published as a nomen nudum by Paris in 1906. (It is not homotypic with Pohlia paucifolia (Hampe ex Jaeg.) Broth., which, based on type material in the Hampe herbarium, is synonymous with Pohlia elongata Hedw.) Pohlia tenuifolia was later redescribed from South America as Mielichhoferia brachycarpa Broth., based on specimens collected in Brazil (Rio de Janeiro, Petropolis, $F$. von Hohnel 66, 156, 332; $\mathrm{H}-\mathrm{Br}$ !). Several other New Zealand Pohlia species recognised by Sainsbury (1955) as endemic need evaluation.

Vitt (1971) described a gemmiferous species, $P$. ochii Vitt, from Campbell Island; this species also occurs in the North and South Islands of New Zealand (Fife 1984). We provide below a description for a new gemmiferous Pohlia, presently known only from the South Island.

Pohlia australis Shaw et Fife, sp. nov. Fig. 1-8 Plantae quoad staturam mediocres vix nitidae. Folia lanceolata ad $2 \mathrm{~mm}$ longa, prope apicem valde serrata deorsum ad medium vel infra medium serrata vel serrulata; 




Fig. 1-6 Pohlia australis 1 Moist plant, $\times 25.2$ Dry plant, $\times 25.3$ Leaves, $\times 50.4$ Upper leaf cells, $\times 360.5$ Apical leaf cells, $\times 360.6 \mathrm{Gemmae}, \times 240$ (from the holotype). 

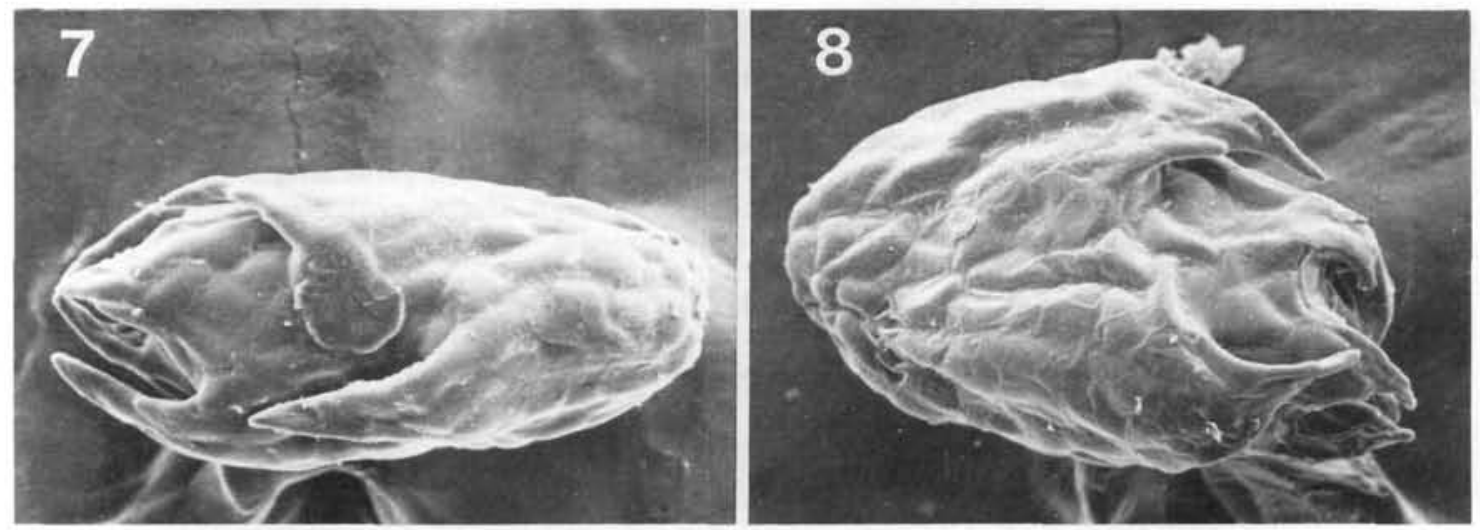

Fig. 7-8 Scanning electron micrographs of gemmae from $P$. australis, $\times 350$.

cellulae lineari-rhomboidea 100-150 $\mu \mathrm{m}$ longae plus minusve vermiculiformes. Gemmae in axillis foliorum superiorum fasciculatae, ovoideae vel oblongae ad $385 \mu \mathrm{m}$ longae et $200 \mu \mathrm{m}$ latae, pallide flavo-brunneae vel brunneae, translucentes, apice et subapice conspicue primordiiferae, primordiis late triangularilaminatis. Caetera ignota.

HOLOTYPUS: New Zealand. South Island: Buller Co., Paparoa Mountains, cirque on east flank of Mt Priestly, 1050-1140 m a.s.l., 12 April 1983, Fife 5487 (CHR 104235).

Plants medium size and rather dull, in small loose tufts, to $1 \mathrm{~cm}$ high, frequently mixed with other species. Stems simple (when sterile), in transverse section terete, about $150 \mu \mathrm{m}$ in diam., with an inconspicuous central strand of small, thin-walled cells gradually grading into larger, thin-walled cells, and 1(-2) layers(s) of thick-walled cells on the periphery. Leaves erect-spreading to spreading, becoming rather twisted when dry, lanceolate, slenderly acute, rather long-decurrent, 1.4-2.0 mm long, $0.25-0.35 \mathrm{~mm}$ wide; margins plane when moist, loosely recurved when dry, strongly serrate near the apex, serrate to serrulate to midleaf or below; costa ending a few cells below the apex, in transverse section with 2-3 guide cells and a group of dorsal stereids; upper leaf cells linear-rhomboidal or linear-hexagonal, vermicular, $100-150 \mu \mathrm{m}$ long, 8-11 $\mu \mathrm{m}$ wide, with thin or firm walls, long-rectangular near the base. Gemmae arising in clusters of three or more in the upper leaf axils, yellow-green to yellow-brown and becoming darker with age, oblong, 200-385 $\mu \mathrm{m}$ long, c. $200 \mu \mathrm{m}$ broad, with 4-9 triangular-laminate leaf primordia at the apex and lower on the gemma body; cells of the body isodiametric to short-rectangular, to $30 \mu \mathrm{m}$ long, those of the leaf primordia more elongate. Inflorescences and sporophytes unknown.
ADDITIONAL SPECIMENS SEEN: New Zealand. South Island: Arthur's Pass National Park, Temple Basin Track, between Route 73 and Lockwood Shelter, 2 Feb. 1984, Fife 6190, 6191a (paratypes: CHR 104236, 104234).

\section{DISCUSSION}

All three collections of $P$. australis were made in the subalpine zone where shrub species (e.g., Dracophyllum longifolium (J. R. \& G. Forst.) R. Br., D. uniflorum J. D. Hook., Olearia colensoi J. D. Hook., and Phormium cookianum Le Jolis) are conspicuous components of the vegetation. The plants were collected from soil-filled crevices and beneath overhanging boulders, microhabitats which are typical of gemmiferous Pohlia species in the Northern Hemisphere. The bedrock of both areas is siliceous and it is evident from the vegetation that the soil is at least mildly acidic. At both localities $P$. australis was growing in proximity to $P$. ochii, which was somewhat more common. At Arthur's Pass the two species were collected intermixed.

Pohlia australis is readily distinguished from $P^{*}$. ochii by its dull leaves and oblong gemmae. It resembles $P$. camptotrachela in the lack of gloss to its leaves, but the gemmae of $P$. camptotrachela are significantly smaller, more spherical in shape, and have inconspicuous, peg-like leaf primordia. In addition, the leaves of $P$. australis are longer than those of $P$. camptotrachela, longly decurrent, and the apices are more strongly serrate. Pohlia annotina (Hedw.) Lindb., occurring in temperate North America and Europe, sometimes has oblong gemmae resembling those of $P$. australis but they are 


\section{KEY TO THE GEMMIFEROUS SPECIES OF POHLIA IN NEW ZEALAND}

1 Plants glossy; gemmae linear-vermicular, greater than $500 \mu \mathrm{m}$ long, with $1-$ 2 short, peg-like leaf primordia ........................................................... ochii

Plants dull; gemmae spherical to oblong, less than $400 \mu \mathrm{m}$ long, with 3-8 peglike or laminate (flattened, multi-cellular, and leaf-like) leaf primordia........

2 Leaves $1.5-2.0 \mathrm{~mm}$ long, strongly decurrent, strongly serrate near the apex; gemmae oblong, 200-400 $\mu \mathrm{m}$ long. leaf primordia broadly triangularlaminate

P. australis

Leaves $0.8-1.4 \mathrm{~mm}$ long, not or weakly decurrent, serrulate near the apex; gemmae spherical, less than $150 \mu \mathrm{m}$ in diameter, leaf primordia short and peg-like.

most frequently orange, and have the leaf primordia more restricted to the apex. The gemmae of $P$. annotina are commonly narrow and obconic, and plants with oblong gemmae superficially resembling those of $P$. australis are relatively rare (Shaw 1981). In contrast to the variable gemmae of $P$. annotina, those of $P$. australis are relatively uniform in shape. These two species can also be distinguished by the longer, more strongly serrate, and decurrent leaves of $P$. australis.

The two groups of Pohlia species producing gemmae appear to represent different phylogenetic lineages (Shaw 1984). The two groups, subgenus Nyholmiella Shaw and subgenus Cacodon section Cacodon (Lindb.) Broth., are distinguished primarily by differences in capsule and peristome structure, but they also differ gametophytically. Plants of Pohlia subgenus Nyholmiella are not glossy, and their sterile stems are frequently much branched. Plants of section Cacodon may be glossy or dull, with the sterile stems unbranched. Using these criteria (sporophytes are unknown in both $P$. australis and $P$. ochit), these two species appear to belong to section Cacodon, as does $P$. camptotrachela (for which sporophytes are known). Pohlia ochii, both in terms of vegetative and gemma characters, resembles $P$. proligera (Lindb. ex Breidl.) Lindb. ex Arn. of the Northern Hemisphere boreal zone, and it is tempting to interpret $P$. ochii as a derivative of it, perhaps having diverged subsequent to colonisation of New Zealand and neighbouring islands.

\section{ACKNOWLEDGMENTS}

We thank Harold Robinson for providing the Latin description and Alice Tangerini for preparing the illus- trations. Elizabeth Edgar provided useful criticism of the text. The second author is grateful for support from the National Research Advisory Council of New Zealand.

\section{REFERENCES}

Catcheside, D. G. 1980: Mosses of South Australia. Adelaide, Handbook Committee of the South Australian Government.

Fife, A. J. 1984: Records of new or otherwise interesting species of mosses in New Zealand, including a new species of Racomitrium. New Zealand journal of botany $22: 1-6$.

Ochi, H. 1970: A revision of the subfamily Bryoideae in Australia, Tasmania, New Zealand and the adjacent islands. Journal of the Faculty of Education, Tottori University, natural science 21: 7-67.

Paris, E. G. 1903-1906: Index bryologicus sive enumeratio muscorum ad diem ultimam anni $1900 \mathrm{cog}$ nitorum adjunctis synonymia distributioneque geographica locupletissimis. ed. 2. Vol. 5. 1906. Paris.

Sainsbury, G. O. K. 1955: A handbook of the New Zealand mosses. Royal Society of New Zealand bulletin 5 : $1-490$.

Scott, G. A. M.; Stone, I. G. 1976: The mosses of Southern Australia. London, Academic Press.

Shaw, A. J. 1981: A taxonomic revision of the propaguliferous species of Pohlia Hedw. (Musci) in North America. Journal of the Hattori Botanical Laboratory $50: 1-81$.

1982: Pohlia Hedw. (Musci) in North and Central America and the West Indies. Contributions from the University of Michigan Herbarium 15: 219-295.

- 1984: Character analysis, phylogeny, and classification of the moss genus Pohlia. Canadian journal of botany $62: 219-229$.

Vitt, D. H. 1971: New species of mosses from Campbell Island, New Zealand. The Bryologist 74 : 464-472. 